\title{
The Bulgarian Occupation Zone During World War II
}

\author{
Haxhi Ademi PhD. Cand. \\ Institute of History "Ali Hadri”, Prishtinë
}

\begin{abstract}
After the invasion of Yugoslavia, especially Kosovo by the German army in World War II (1941), Kosovo was divided into three occupation zones, which were defined in the Vienna talks. In addition to the interests of of the big countries like Italy and Germany, the latter also sought to meet the demands of Bulgaria, another ally of the Fascist Bloc. Thus, Bulgaria sought to pass under its rule a part of the districts of Gjilan, Vitia, Old Kacanik, the region of Presevo, Kumanovo, Skopje, Veles, Prilep and Bitola. In these regions lived about 200.000 Albanians, who came under Bulgarian occupation. Thus, the Bulgarian occupation zone covered an area of $900 \mathrm{~km}^{2}$, with 60.842 inhabitants, or $8 \%$ of the total area of Kosovo and over $9 \%$ of its population. The Bulgarian invaders declared all Albanian territories annexed by them as an integral part of the Bulgarian Kingdom. The policy followed by the Bulgarians against the Albanians during their rule in these areas was usually of the ordinary brutality. Albanians were interned, imprisoned, and killed in the most inhuman ways. In others word, they have been denied every national and human right. As a result of the violence and pressure on the part of the Bulgarian invaders, by September 1942, 3.000-4.000 Albanians were displaced from their lands invaded by the Bulgarians.
\end{abstract}

Keywords: World War II, Kosovo, Albanians, Bulgarians, occupation zone, etc.

\section{Introduction}

\section{The Partition of Kosovo in Occupation Zones}

From The beginning of the year 1941, the political situation in the Balkans became worse and reached its peak on April 6th, when the 12th German division backed by Italian and Hungarian troops, started the war against Yugoslavia and Greece. (AlHT, A-VIII-297, 1977, 19) The ongoing attacks against Yugoslavia lasted until May 17, (Fjalori Enciklopedik, NZh, 2009, 2129) forcing it to sign a declaration of surrender (in the building of the Czechoslovakian embassy), which entered into force on 18 May 1941. (Ali Hadri, 1978, 15). The conquest was accompanied by the dismemberment of the Yugoslavian territory between the German, Italian and Bulgarian invaders. The intentions of the fascist bloc, which were toward realization, included also the Albanian territories. (Historia e Popullit Shqiptar IV, 2008, 129-130).

With the conquest of Yugoslavia and Greece, the Axis Alliance aimed at almost the entire continent of Europe. Thus, after the war of April 1941 the Yugoslavian Kingdom de facto ceased to exist as a kingdom. The Allies also divide the areas of interest between them. With the initiative of Hitler from 27 March the orientation plan has been drafted, which that was concretized on 12 April in "the temporary intentions for the separation of Yugoslavia“. With the initiative of the German foreign Minister Ribbentrop a meeting was organized in Vienna (18 to 23 April 1941) in order to reach an agreement on the final division of Yugoslavia. In addition to Ribbentrop, his Italian counterpart, Galeaco Ciano, and other personalities participate in this meeting who are interested in the partition of Yugoslavia. (Ali Hadri, 1978, 15)

At the Vienna meeting, an agreement was reached between representatives of Berlin and Rome, where the new political map of the Balkans was assigned. Its boundaries were based on the principles of dividing the zones of influence between Germany and Italy, not leaving aside the interests of Bulgaria (Kristo Frashëri, 2008, 295), which were accepted by Germany. The interests of these three Allied countries coincided in the Albanian lands, which were within Yugoslavia. Therefore, after the invasion of Kosovo on 12 April 1941, it was divided between those three states: Italy*, Germany** and Bulgaria. (Historia e Popullit Shqiptar IV, 2008, 129-130)

We will focus only on the Bulgarian occupation zone, which is the main subject of this study. Thus, Bulgaria's interests in the Balkans were discussed as well in Vienna. Therefore, finding support at its German-Italian allies, it was decided to pass 
under Bulgarian rule a part of Kosovo and other Albanian regions of todays Macedonia. Thus, within the Bulgarian area, belonged a part of the districts of Gjilan, Vitia, Old Kaçanik, Presevo, Kumanovo, Skopje, Veles, Prilep and Bitola (Muhamet Shatri, 1997, 20; Historia e Popullit Shqiptar IV, 2008, 129-130). In these regions there lived about 200.000 Albanians who came under Bulgarian occupation.

Despite the agreement reached between the allies in Vienna (23 April 1941), its implementation posed practical problems throughout the existence of occupation zones. All this is due to internal and external factors. The internal factor is related to the demands of the Albanians to join the Italian area, in which the rights of Albanians were more guaranteed than in the Bulgarian one, while the external factor was mainly related to the claims of Bulgaria and Italy to extend their influence as far as possible.

Thus, the initial agreement foresaw that not only Mitrovica, but also a part of the Mitrovica-Prishtina-Ferizaj railroad, and even Prishtina and Ferizaj to join the German occupation zone (Ali Hadri, 1978, 16). The German version was similar with the Italian one in terms of the border assignment in Kosovo, but the Italian version was wider. This was foreseen for the establishment of the border in the Bulgarian zone and foresaw also that Old Kaçanik and Sterpca, which had an Albanian majority and were given to Bulgaria (Ali Hadri, 1978, 16), to become part of the Italian zone. Later, because of the abovementioned interests, the line of demarcation did not remain the same as the invasive states had agreed. This is due to the fact that the Italians expanded their area, including even Pristina and Ferizaj, and to Orllovic's Sukla, the border between the invasive zones of Germany, Italy and Bulgaria was set in the Suka of Orllovic (AQSh, F. 149, v.1941, d. I-1170, 93).

\section{The stationing of the Bulgarians in Kosovo and the creation of their own zone}

In the spirit of the Vienna Agreement and for the purpose of determining the demarcation line between the German and the Bulgarian zone, a meeting was held in Vranje on 11 June 1941. The German commission consisted of Colonel Botmer and senior military advisor dr. Hanle, while the Bulgarian commission consisted of Colonel Stomatova and Lt. Colonel Matikarov. At this meeting, an agreement was reached whereby the border line between the German and Bulgarian zones was established, in Valladicak in the center of Kukavica, then the northern boundary of the Vranje district (Fehmi Rexhepi, 1998, 63). Thus, in Kosovo the Bulgarian occupation zone included the today's municipality of Gjilan (20 villages), Vitia (22 villages), and Kamenica (5 villages), with a surface of $411 \mathrm{~km}^{2}$ and within this area lived 32.196 inhabitants. In the Bulgarian occupation was also Ferizaj and his surrounding (16 villages) included, with an area of $189 \mathrm{~km}^{2}$ in which lived a population of 12.772 inhabitants, and the surrounding of Kaçanik (42 villages), with an area of $300 \mathrm{~km}^{2}$ and 32.196 inhabitants, were lived 15.874 people.

So the Bulgarian occupation zone, alone in Kosovo included 103 villages with a surface of $900 \mathrm{~km} 2$ with 60.842 inhabitants, or $8 \%$ of the territory and over $9 \%$ of his population (Muhamet Shatri, 1997, 20).

Likewise, many Albanian villages of towns like Struga, Tetovo, Gostivar and Kerçova, that were included under the Italian occupation zone, remained under Bulgarian rule. (AQSh, F. 149, v. 1941, d. I-1170, 93). On the basis of a letter dated 28 May 1941, by Riza Drini (Prefect of Shkodra with missions in Struga), addressed to the Prime Minister Shefqet Verlaci, we learned that the Italian troops withdrew from the town of Ohrid and that the town of Struga is in danger (AQSh, F. 149, v. 1941, d. I-1170, 93).

Immediately after the invasion of these zones, two battalions of the Bulgarian invading troops were deployed to this areas to keep the situation under control. Regarding the Bulgarian official policy, it can be said, that there is a continuation of their policy during the First World War*, as Serbo-Croatian was replaced with Bulgarian in all administrative levels, including education (Noel Nalcolm, 2011, 371-372.). Moreover, the whole administrative personnel came from Bulgaria.

But the Bulgarian government was dissatisfied with regard to the area of influential. This dissatisfaction was expressed on 2 September 1941, by the Bulgarian President, Fillovi and the Army Minister Daskallov. Besides that, they stated that they are not satisfied with the designation of the border line in Western Macedonia nor with the attitude of Italy (Ali Hadri, 1971, 99). Despite this, the Bulgarian leadership didn't want to break their relations with Italy in this issue. But, according to them, the demarcation should answer the historical, strategical and economical viewpoint (Ali Hadri, 1964, 679). Despite their dissatisfaction and their constant demands, the demarcation line between the occupation zones of Italy and Bulgaria was never change, with the exception of the town Ohrid. 
That what the Bulgarians didn't reach in the case of the demarcation line with the Italian zone, they achieved with the German one. So the Bulgarians couldn't manage to extend their occupation zone into the Italian area, but they could do so in the direction of the German zone, because of the Germans' demand (Ali Hadri, 1964, 680). According to the German Commander for Southeast, dated on 20 December 1941, the Bulgarian occupation zone was supposed to include, among others, the majority of Kosovo with centers such as Pristina and Mitrovica (Ali Hadri, 1971, 99). However, Hitler didn't allow Bulgarian troops to be placed in these towns at that time, but allowed that the Bulgarian occupation zone to expand later. Thus, on 15 January 1942, the districts of Llap were included within the occupying zone, and on 7 January 1943 the districts of Mitrovica and Vushtrri became part of this zone. The enlargement of the Bulgarian occupation zone has been done with the good will of the Germans, as it was interested that Bulgaria defends the backward line in southeastern Serbia, so that the German troops can be used on the eastern front. (Ali Hadri, 1964, 680).

On the other hand, none of the conquered peoples like the Serbs, Montenegrinians and Albanians were satisfied with the demarcation line (Ali Hadri,1964, 680). The Italian government insisted that Sterpca and Old Kacanik should become part of their occupation zone, arguing with the fact that the vast majority of their population was Albanian. However, the Italian demands collided with those of the Bulgarians, and therefor she insisted that the borders of her ruled zone shouldn't be touched. For this attitude, Bulgaria found Germany's support, which had secured the right to exploit Bulgarian mining assets. Overall, in the summer of 1943, a re-enactment of the borders between the Italian and Bulgarian occupiers took place in the area of the sub-prefecture of Gjilan. So, the Italian zone was joined by the villages like Sadovinë of the Jerli and Verbani (today villages of the Vitia municipality), then Godanci (today a village in the municipality of Shtime) and some other villages. The controversy between Bulgaria and Italy over the expansion of the occupation zones lasted until September 1943, when the latter capitulated. After the capitulation of Bulgaria, in September 1944, Albania's borders expanded to the vicinity of Skopje and from there to Kumanovë, Preshevë and Bujanocë (Muhamet Shatri, 1997, 20).

\section{The position of Albanians in the Bulgarian area}

The Bulgarian conqueror proclaimed all the Albanian lands annexed by them as an integral part of the Bulgarian Kingdom. Bulgaria followed a tolerant policy towards the Serbian population in these areas, which aimed at their assimilation because they considered them as Moravian Bulgarians (Idriz Halabaku, 1978, 470). This policy of the Bulgarians against the Serbian people was followed by the beginning of the year 1943. Unlike the Serbs, the Bulgarians pursued a very discriminatory policy against the Albanians during their reign (August 1941 - September 1944). They were interned, imprisoned, murdered in brutal ways. Thus the Albanians in this zone of occupation were denied every basic right. (Muhamet Shatri, 1997, 32).

Immediately after the occupation, the Bulgarians began with the administrative-judicial and police-military arrangements, which was done in several phases. Firstly, a military reinforcement took place in the middle of April 1941. Even during the months July-August, the supreme Bulgarian commander made a military reorganization by moving huge military forces into the occupied territories, while in the occupied zone of Kosovo, 2-3 battalions were placed with a total of 450 to 500 soldiers who were distributed in the municipality of Kaçanik district. Most of the Bulgarian soldiers were deployed along the ItalianBulgarian border, while the main military headquarter was located in Zhegër.

In the Bulgarian occupied zone in Kosovo there was only one police circle located in Kaçanik, which had 81 police officers. In Kaçanik district, there existed also a cohort of counter armed groups, consisting of 40 people, placed 10 in Kaçanik, about 20 in Viti and several others where they were needed. The people of these cohorts were Bulgarians, who were placed in these lands during the Balkan Wars and the First World War. They had salaries and were paid for obligations, i.g. against those with anti-Bulgarian disposition. After regulating the military-police, it also makes the administrative and judicial territorial regulation of other bodies and institutions. The country was divided into districts and districts into municipalities. At the head of these institutions stood the provincial director and the district director in the kmeti municipalities (alderman). Each village had a superior kmet who answered to the mayor. In every state institution worked a number of officers who were in charge of propagating the Bulgarian language (Daut Bislimi, 1997, 57).

\footnotetext{
$\square$ The attitude of the Bulgarian politics caused in the first place the Serbian people to create illusions that with the help of the Bulgarian power they would oppose the Albanians. During the Bulgarian occupation, there were several cases where Serb families living in the Italian zone crossed over to the Bulgarian occupation zone, as a result of the conditions provided by the Bulgarians to the Serb population. This conditions were only in the area of occupation in Kosovo, but in the occupation zone in Macedonia Serbs did not have this position.
} 
In a report of Ramadan Presevo* submitted to the High Commissioner for Kosovo, Dibra and Struga-Prizren reported the Bulgarian atrocities against the Albanian population in the provinces of Presheva, Kumanova, Skopje, which took place in the period between 10th and 17th of May 1941. In this report, among others ist stated "In the prefecture of Presheva, in the village of Shunicë (Zhunicë) they have beaten the village chief Adem Mehmeti, because he did not let them plunder the village, then the Bulgarian Army has robbed by accident garments of women and grain, and beside these they have beaten many people in the village and have also plundered 7,000 pounds of grain and 20,000 pound of grass... also in Sumolic village they have plundered the clothes of the mosque... this report presents the violence exercised by the Bulgarian army in the villages of Cenotic, Bilic, Negofe, Noesel, Trnoc... In Skopje, more than 50 people were imprisoned, just because they have placed white plis on their head... about these 50 people, we were for a few days unaware of their fate. Likewise, dozens of other people were beaten and robbed in this city, and even by the violence exercised by the Bulgarian police, Muhmut has died". (AQSh, F. 23, v. 1941, d. 25, 236). Always according to this document "On the 13th day of the month, market day, the Bulgarian army had placed machine-guns, each with eight soldiers to gather the people and to rip down their white plis, which made it clear that you are not a Shqyptar but you are a Bulgarian, and of these more than 300 were imprisoned at Jahja Pasha's Mosque where they were kept arrested until 6 o'clock after lunch". In this case Ramdan Presheva himself was a witness. "Also on 13th, on the road called Toptana coming from Kaçanik, from more than 300 young people their white plis have been torn in pieces and they have been imprisoned in the barracks called Tophane and nothing is known about their situation" (AQSh, F. 23, v.1941, d. 25, 237) In a letter from the deputy prefect of Gnjlane, Yahya Bacaj, sent on September 17th 1941, to the High Civil Commissariat for Kosovo, Debar and Struga and the the Prefecture of Pristina, through which the latter announced that 21 Albanian families because of persecution by Bulgarians, as well as others due to the political nature were forced to flee their homes and settle within the Albanian border (AQSh, F. 23 , v. 1941 , d. $25,245-246)$.

In an information from the deputy prefecture of Gjilan, dated 4th of October 1941, reported to the Prefecture of Pristina on the killing of Isuf Hamid by the Bulgarian army. They also called for intervention in order to take action through diplomatic ways to stop the violence exercised systematically by the Bulgarian army to the detriment of the Albanian element. (AQSh, F. 167, v. 1941, d.72, 45-46). During the year 1941, there were successive requests directed to the authorities like the senior civilian commissar, and the leaders of the prefectures and sub-prefectures who were informed about the plundering of the population, mistreatments, imprisonments, and killings of the Albanian population by the Bulgarian invaders. Such is the request from the sub-prefect of Gostivar, Xhavit Kallajxhiu, sent on 16 December 1941, to the prefect of Dibra, whereby the latter is informed of the mistreatment and plundering of Albanian citizens by Bulgarian guards at the border crossing point in Zhelino (AQSh, F. 266, v. 1941, d. 80, 1) There were also problems in relation to the occupation zone during 1941. Thus, after the withdrawal of the Italian army from the town of Ohrid, anxieties began to spread around the Albanian and Serbian population, as a result of the psychological pressure exerted by the Bulgarian army on the civilian population. The Albanian population was very concerned, because "...news are spread that Bulgaria is trying to get Struga as well" (AQSh, F. 149, v.1941, d. I-1170, 93).

A law issued at the end of 1941 threatens with death penalty for "any form of propaganda against the Bulgarian state“(Noel Nalcolm, 2011, 371-372) It looks like the law on protection of the state (Zakon za zastitata na drzavata), which came into force on 16 December 1941. (Fehmi Rexhepi, 1998, 58) Through this law, sanctions were extended to all those who attacked or violated the ruling Bulgarian regime. Based on the research done at the Albanian Central State Archive, which contains dozens of documents that inform us about the violence and pressure exerted by the Bulgarian army against the Albanian population, who were forced to move from their territories.

During 1942, the Bulgarian invaders excessively increased the violence against the Albanian population, mostly at the border crossing points where the large Albanian families were mistreated. Based on a letter dated 20 January sent by the Prefecture of Dibra, which reaches up to the General King's Vicar, we learn about the mistreatments of the Albanian families from Jellovic of Gostivar at the border point by Bulgarian guards. (AQSh, F. 266, v.1942, d. 80, 2-3)

With the goal of being well-informed about the position of Albanians in the Bulgarian occupation zone and the position of Bulgarians in the Italian occupation zone, the General King's Vicar sent a letter on 5 March 1942 to the Ministry of Free Lands, through which the latter sought information (AQSh, F. 266, v. 1942, d. 83, 1-3).

Ramadan Presheva, a member of the Kosovo Committee. 
According to a letter, the Bulgarian government will announce from 17 April on, the mobilization of all inhabitants, where there will be mobilized all from the birth year 1887 to 1923 (at the age of 19-55). This call invites all residents not to avoid this call. From this call, „many Albanians and a part of Gostivar took advantage of the case, to cross the border" (AQSh, F. 152, v.1942, d. 402, 1).

With a letter from the Inspector General for Kosovo, sent on 28 May 1942, informs Koço Tasi the Prime Minister „about the ill-treatment of 700 (seven hundred) Albanian by the Bulgarian authorities; men, women and children from the areas under Bulgarian control cross the boundary to the Municipalities of Partesh and Pozharan and resettled on Albanian land in the villages of Gjilan and Ferizaj, near the border" (AQSh, F. 814, v.1942, d.14, 5). About these ill-treatments the general inspector for Kosovo Koço Tasini, informed on 28 May 1942 also the Prefecture of Prishtina as well as the sub-prefectures of Gjilan and Ferizaj (AQSh, F. 814, v. 1942, d. 14, 7). He is also informed on 9 June 1942 about the murder of the farmer Ibrahim Hasani by Bulgarians (AQSh, F. 152, v. 1942, d. 405, 2).

But despite the expansion of Bulgarian space, yet the Bulgarians were still not satisfied with the occupation zone and their claims for expansion of their zone were perpetual. In order to achieve these objectives, the Bulgarian authorities had organized various circles to exert pressure on the Albanian population, which would be forced to leave their homes. According to a document, it is proved that such organizations "in the village Klemeshtan of the Municipality of Meshavishit in the district of the sub-prefecture of Struga, is often seen a group of about 180 people armed with rifles, machine guns and bombs. Based on our information, this armed group came from Bulgaria" (AQSh, F.152, V.1942, d. 293,41). In order to accomplish its goals, the Bulgarian occupiers activate extreme Macedonian-Bulgarian circles, and from 1942 on also the relations to the Chetniks of Drazha Mihajlovic (Muhamet Shatri, 1997, 32).

The discriminatory policy followed by the Bulgarians provoked the displacement of Albanians from their own lands. Thus, in a report by the Ministry of the Free Land on September 1942, it was noted, that as a result of violence and pressure by the Bulgarian occupiers until September 1942, more than 3.000-4.000 Albanians are displaced from the Bulgarian occupied zones (Muhamet Shatri, 1997, 32). Meanwhile, in another report that came from the same minister stated that „more than 3.000 Albanian inhabitants of the Karadag Mountains in Kosovo, Kumanovo, Kacanik, Presevo, Skopje, Bitola have been forced to abandon their homes and are in difficult conditions in Gjilan, Ferizaj, Tetovo and Debar". (AQSh, F.151, v. 1944, d. $71,1-11)$. In the Bulgarian occupation zone during the whole period of their rule, the Albanian population also suffered for the most essential things such as bread. This is best explained by the fact that in Struga's sub-prefecture with about 60.000 inhabitants, at least half of the population was in need of bread. (AQSh, F.886, D.1103, 1) Whereas, in a report about the inhabitants of Kaçanik, it is said that residents need grain. Furthermore, this report describes the situation best, where Albanians were not allowed by Bulgarian authorities to take $20 \mathrm{~kg}$ of grain which they bought in Albania, because it was considered as smuggling. (AMPJ, F.151, V.1944, d. 99, 14)

In a telegram dated 31 from the Prefecture of Dibra, was asked for a diplomatic demarche directed to the Bulgarian government for not torturing Albanians. This notice stated, inter alia: "Information from reliable sources state that the Bulgarian authorities started on 27 to mistreat Albanian minorities in Bitola and Prilep. They have arrested a large number of them, and it is not exactly known where they are" (AQSh, F.149, v. 1944, d. 99, 29).

With a request, the Albanians in the Bulgarian occupation zone seek weapons in order to protect themselves from the Bulgarian and Serbian authorities. In this claim, they had reflected in detail the killings of children from the age of 2 years, who was killed with his father Ramiz Durmishi, up to the age of 70, such as the murder of Rexhep Sherif and dozens of other people and injuring hundreds of others. This document reflects the event of August 15, during which the Bulgarian authorities, in cooperation with the Serbian partisans, attacked believers who were performing the religious obligation during the Taravian time, four of whom died and 24 were injured (AMPJ, F.151, v.1944, d..99, 45-51).

In a document on the massacres against Albanians across the border, on 16 December 1943 of the Gjilan sub-prefecture directed to the Prefecture of Pristina "'One person named Osman Halili from the village of Svirca of the sub-prefecture of Medvedja and resident in Gjilan has addressed us in an official form to say that: The Drazhistas that are in the Medvedje sub-prefecture and who bear the name Karovski Adred were committing massacreds in the villages of Svirce, Tuplje and Gërbac, which are Albanian, and the Ravana, Banja, Stara-Banja, Llapashtica, Kapit, Sjarnica, Gjylekari and Medvedja villages that are mixed, and in all these can be more than 400 spirits. The massacres are been done in order to force the people leave from there and come to this side (AMPJ, F.151, v. 1944, d.176, 12). 
Throughout the period of the Bulgarian rule, demands from the Albanian side for the unfair treatment by the Bulgarians have been done continuously. This proves a request by the Central Committee of the Second League of Prizren, addressed to the Presidency of the Council of Ministers and the Prime Minister, authorizing the Minister of Foreign Affairs, to submit to the Bulgarian authorities the request from the Albanian side, among other things it is said "...many villagers of the Gjilan district have their lands beyond the demarcation line, under Bulgaria, and they have the need to cross over in the Bulgarian regions from time to time ... we are therefore asking for appropriate steps that should be taken by the Bulgarian Consulate General and the competent authorities of Sofia ... to allow the people in question to cross the line of demarcation..."(AMPJ, F.151, v.1944, d.176, 12).

On the other hand, the Bulgarian government, rather than prohibiting the discrimination of Albanians, it continued even to intensify their mistreatment. From an archive document we learn about the improper treatment of Albanians, where among other things is said: "...the Bulgarian government has for days intentionally called for the mobilization of all Albanian citizens that lived in its occupation zone, aged 18-45 ... and sends them to distant places and heavy work and no one should dare to opposes this illegal call..."(AMPJ F.151, v.1944, d. 99, 56).

About the torture against the Albanian population, we learn from a report that asked the Albanian authorities to engage in a vigorous intervention and stop such actions from Bulgarians (AMPJ, F.151, v.1944, d.972, 1). While in another report on the Bulgarian cruelty against the Albanians of Skopje, Kumanovo, Presevo, Gjilan, accurate data are provided about the atrocities, imprisonments and killings of the Albanian population by the Bulgarians, where the number of the first is enormous. (AMPJ, F.151, v.1944, d.99, 36)

From the facts described above, we can conclude that the Bulgarian invader in the area of his occupation, pursued an assimilation policy towards all peoples living in the area. So the Macedonians were called Bulgarians, the Serbs Bulgarians of Anamorava, while a discriminatory and humiliating policy was applied towards Albanians. For this reason, the Albanian nationality was undergoing an unprecedented oppression by the Bulgarian occupiers. She did not enjoy basic and national rights. Moreover, no right at all were given such as the right to use the flag, the celebration of historical dates, the opening of schools in Albanian language, etc. Therefore many Albanians have been forced to leave their lands, just to be able to escape the violence of the Bulgarian pressure.

In the Bulgarian area, to oppose the Albanian efforts for emancipation and education in their mother tongue, an organization called "Orle" was formed, which was for primary school children aged 7-14. This pro-fascist and great Bulgarian organization worked to educate and teach the children in the Bulgarian fascist spirit. Thus, the Bulgarian teachers taught the children fascistic songs and poems, then drove them to the streets to sing Bulgarian songs and taught them to salute the fascistic way. (Fehmi Rexhepi, 1998, 82).

But Albanian children from some of the villages of Gjilan and Kaçanik, which were part of the Bulgarian occupation zone, managed to secretly attend the Albanian language courses, which took place in the Italian occupation zone. Thus, in a report by the Presidency of the Extraordinary Kosovo Education Mission sent on 19 September 1941, it is said that "the opening of the summer courses in Kosovo has been one of the few and the most beautiful works that the Albanian state has conducted in those places ... the courses included the rest of the Albanians outside the todays borders, from some villages of Gjilan and the district of Kaçanik..." (AQSh, F. 195, v. 1941, d.180, 111).

\section{Conclusion}

In conclusion, we can say that in the Bulgarian occupation zone, the Albanians did not enjoy even the basic human, national and civic rights. This is because the Bulgarian state, working in harmony with the plans of the Nazis, choose no other way than the fascist dictatorship. This systematic violence that Bulgaria did during the Second World War over the Albanian population was realized through the army of this country. In addition to the military, this form of violence was also realized through the Bulgarian state apparatus with its functions, as well as by the fascist organizations operating in this country. All these efforts resulted in enormous consequences for the Albanian population of this part. Reports of displacements, murdering, imprisonments and torture of Albanians on the daily basis, while the lack of Albanian schools, the lack of Albanian civil servants in the administration, the denial of national rights had become a practice followed by the official policy of the Bulgarian state.

\section{Bibliography}




\section{Archival Sources, Unpublished Sources}

[1] Arkivi Qendror i Shtetit të Republikës së Shqipërisë (AQSH)

[2] Arkivi i Ministrisë së Punëve të Jashtme i Shqipërisë (AMPJ)

[3] Arkivi i Instituti të Historisë- Tiranë (AlHT)

\section{Literature}

[1] Fjalori Enciklopedik Shqiptar, (2009), Botim i ri, Vëllimi i tretë: N - Zh dhe një shtesë, Akademi e Shkencave e Shqipërisë - Qendra e Enciklopedisë Shqiptare, Tiranë.

[2] Bislimi. Daut, (1997), Formacionet politiko-ushtarake në Kosovë (1941-1945), Instituti Albanologjik i Prishtinës, Prishtinë.

[3] Frashëri. Kristo, (2008), Historia e qytetërimit Shqiptarë (Nga kohët e lashta deri në fundin e Luftës së Dytë Botërore, Akademia e Shkencave e Shqipërisë, Tiranë.

[4] Hadri, Ali. (1971)Lëvizja Nacionalçlirimtare në Kosovë, 1914-1945, Rilindja Prishtinë:

[5] Hadri. Ali, (1978), "Sistemi i pushtimit Fashist në Kosovë"(1941-1944), KOSOVA, Nr. 7, Instituti i Historisë, Prishtinë.

[6] Hadri. Ali, (1964), “Sistemi okupues në Kosovë- Metohi”, PËRPARIMI, nr.11-12, Prishtinë.

[7] Halabaku. Idriz, (1978) "Zona pushtuese bullgare në Kosovë dhe sistemi pushtues (1941-1944), KOSOVA, nr. 7 , Instituti i Historisë, Prishtinë.

[8] Hashani. Shaban, (1998), Ferizaj dhe rrethina 1873-1941 (vështruar nga pikëpamja historike), Ferizaj.

[9] Historia e Popullit Shqiptar III, (2007), Periudha e Pavarësisë 28 Nëntor 1912- 7 prill 1939, Akademia e Shkencave e Shqipërisë, Toena, Tiranë.

[10] Historia e Popullit Shqiptar IV, (2008), grup autorësh, Instituti i Historisë, Tiranë.

[11] Nalcolm. Noel, (2011), Kosova, Një histori e shkurtër, Koha, Prishtinë.

[12] Rexhepagiq. Jasha, (1968), Zhvillimi $i$ arsimit dhe $i$ sistemit shkollor të kombësisë shqiptare në territorin e Jugosllavisë së sotme deri në vitin 1918, Enti i Teksteve dhe i Mjeteve Mësimore të Kosovës, Prishtinë: 1968;

[13] Rexhepi. Fehmi, (1998), Gjilani me rrethinë gjatë Luftës së Dytë Botërore (1941-1945), Instituti i Historisë, Prishtinë.

[14] Rushtiti. Liman, (1986), Rrethanat politiko-shoqërore në Kosovë 1912-1918, Rilindja, Prishtinë.

[15] Shatri. Muhamet, (1997), Kosova në Luftën e Dytë Botëror 1941-1945, Institut i Historisë, Prishtinë. 